\title{
Interaction between GIS and hydrologic model: A preliminary approach using ArcHydro Framework Data Model
}

\author{
doi: 10.4136/ambi-agua.1251 \\ Received: 29 Nov. 2013; Accepted: 16 Dec. 2013 \\ Silvio Jorge C. Simões \\ Universidade Estadual Paulista (UNESP) - Campus São José dos Campos, SP, Brazil \\ Departamento de Engenharia Ambiental \\ Instituto de Ciência e Tecnologia - ICT \\ *Autor correspondente: e-mail: silvio.simoes@ict.unesp.br
}

\begin{abstract}
In different regions of Brazil, population growth and economic development can degrade water quality, compromising watershed health and human supply. Because of its ability to combine spatial and temporal data in the same environment and to create water resources management (WRM) models, the Geographical Information System (GIS) is a powerful tool for managing water resources, preventing floods and estimating water supply. This paper discusses the integration between GIS and hydrological models and presents a case study relating to the upper section of the Paraíba do Sul Basin (Sao Paulo State portion), situated in the Southeast of Brazil. The case study presented in this paper has a database suitable for the basin's dimensions, including digitized topographic maps at a 50,000 scale. From an ArcGIS ${ }^{\circledR} /$ ArcHydro Framework Data Model, a geometric network was created to produce different raster products. This first grid derived from the digital elevation model grid (DEM) is the flow direction map followed by flow accumulation, stream and catchment maps. The next steps in this research are to include the different multipurpose reservoirs situated along the Paraíba do Sul River and to incorporate rainfall time series data in ArcHydro to build a hydrologic data model within a GIS environment in order to produce a comprehensive spatial-temporal model.
\end{abstract}

Keywords: geospatial analysis, water resource management, Paraíba do Sul Basin.

\section{Interação entre SIG e modelo hidrológico: Uma abordagem preliminary usando o ArcHydro Framework Data Model}

\section{RESUMO}

Em diferentes regiões do Brasil, o crescimento populacional e o desenvolvimento econômico podem degradar a qualidade da água comprometendo a saúde das bacias hidrográficas e abastecimento humano. Sistemas de Informação Geográfica (GIS) constituem uma ferramenta poderosa para o gerenciamento dos recursos hídricos, evitando inundações devido à sua capacidade de colocar, em um mesmo ambiente, dados espaciais e temporais que possibilitem a criação de cenários que contribuem para a gestão de recursos hídricos. Este artigo discute a integração entre GIS e modelos hidrológicos e apresenta um estudo de caso que corresponde à parte superior da bacia Paraíba do Sul (porção de São Paulo) situado no Sudeste do Brasil. O estudo de caso apresentado neste artigo tem um banco de dados que é adequado para a dimensão da bacia incluindo mapas topográficos digitalizados em escala 
1:50.000. Neste projeto foi utilizado o ArcGIS ${ }^{\circledR} /$ ArcHydro FrameWork Model Data onde foi criada uma rede de dados topológica para produzir diferentes produtos matriciais. O primeiro mapa derivado do Modelo Digital de Elevação (MDE) foi o mapa direção de fluxo seguido pelo mapa de acumulação de fluxo e mapa de sub-bacias. Os próximos passos desta pesquisa devem incluir os diferentes reservatórios multiusos situados ao longo do rio Paraíba do Sul e incorporar dados de séries temporais de chuvas no ArcHydro com o objetivo de construir um modelo de dados hidrológicos dentro de um ambiente SIG a fim de produzir um modelo completo com componentes espaciais e temporais.

Palavras chaves: análise geoespacial, modelo hidrológico, gerenciamento de recursos hídricos.

\section{INTRODUCTION}

The management of water resources is naturally a concern of many countries and communities. In different regions of Brazil, population growth and economic development can degrade water quality, compromising watershed health and human supply. Decreases in the availability of water, degradation of water quality, and hydroclimatologic disasters (e.g. floods and landslides) are common in many Brazilian hydrographic basins including the Paraíba do Sul watershed, where several problems directly affect the management of water resources. On the other hand, a cycle of wet and dry years has occurred, leading to extreme floods and long periods of drought in the last decades (Simoes and Barros, 2007).

Because of its ability to not only organize, analyze, and manage geospatial data, but also to contribute to creating models for water resource management (WRM), the Geographical Information System (GIS) is a powerful tool for aiding in flood prevention, water supply estimation, and the management of water resources. For this reason, GIS is ideally suited for WRM activities that need to use spatial and temporal data from different sources. GIS is particularly useful in using different spatial analysis techniques to represent spatial variability related to hydrological cycle elements including precipitation, infiltration, and water quality. (Soares et al., 2012; Faria, 2012)

Because hydrologic phenomena are both spatially and temporally dependent, it is important that GIS and hydrological models integrate geospatial components, such as topographic and soil data, and time series data of precipitation, streamflow and river sedimentation. For this reason, distributed models represent the hydrologic process of the watershed in more detail than lumped models, which do not consider watershed spatial variability (Clark, 1999). However, distributed models are generally more complex, thus requiring more data, more computational resources, and more development time than lumped hydrologic modeling.

A major limitation to in the use of distributed hydrological models in water resource management is the lack of detailed data, especially topographic data. Different distributed hydrological models (e.g. TopModel) use DEM as a primary and essential input to watershed analysis and monitoring. However, in many Brazilian regions, there are no consistent national or regional surveys of topographic data which could provide detailed information about the watershed geomorphology characteristics. However, new geotechnological tools are currently available such as the SRTM (Shuttle Radar Topography Mission) that is used widely as source of Digital Elevation Model (DEM). The SRTM represents the radar reflective surface; it was collected in 2000 and is now available at a horizontal spatial resolution of 90 meters (averaged from 30 by 30 meters) at vertical increments of 1 meter (Maathuis and Wang, 2006). The data can be downloaded freely (http://srtm.usgs.gov), unzipped and processed. For Brazil, INPE has resampled the original SRTM-90 m data by kriging to a $30 \mathrm{~m}$ resolution, followed by morphometric analysis using GIS-based algorithms (Valeriano, 2005). 
Different distributed hydrological models have been developed for operating within a Geographical Information System and can vary significantly because they could be used for several purposes. As an example, the free ArcHydro model was developed for building hydrologic information systems to synthesize geospatial and temporal water resources data that support hydrologic modeling and analysis (Maidment, 2002). This model has been used for different applications associated with water resources management such as flood analysis, water resource management and stream extraction from DEM ou LIDAR data (Ramroop, 2005; Colson et al., 2006; Kawasaki et al., 2008a, 2008b; Karagiozi et al., 2011). The model is developed as an Add-on to ArcGIS software being used to extract topologic variables from a digital elevation model raster (DEM) for building geometric networks for hydrologic analysis (Dost, 2005; Kraemer and Panda, 2009). The complete model consists of five categories to divide water resource elements, such as network, drainage, channel, hydrography, and time series. The ArcHydro tool generates several datasets that collectively describe the drainage pattern of a catchment. Most watershed managers need this facility for watershed management.

Therefore, the main objective of this study was to develop a preliminary geo-spatial model using the potentiality of integration between ArcGIS ${ }^{\circledR}$ and ArcHydro. The results correspond to the first part of the research and a simplified version of ArcHydro - named ArcHydro Framework - is used to obtain information about river network, watersheds, and monitoring points. The Paraíba do Sul Basin (Sao Paulo State portion), situated in Southeastern Brazil was chosen for this study because it has a large geodatabase available that could be compared with the results of this work.

\section{MATERIALS AND METHODS}

\subsection{Study area characteristics}

The study area corresponds to the upper section of the Paraíba do Sul Basin (Sao Paulo State portion), covering an area of close $14,500 \mathrm{~km}^{2}$ (CEIVAP, 2011). The Paraíba do Sul River has $1,145 \mathrm{~km}^{2}$ long and drains $55,400 \mathrm{~km}^{2}$ of the Sao Paulo, Minas Gerais e Rio de Janeiro states (Figure 1).

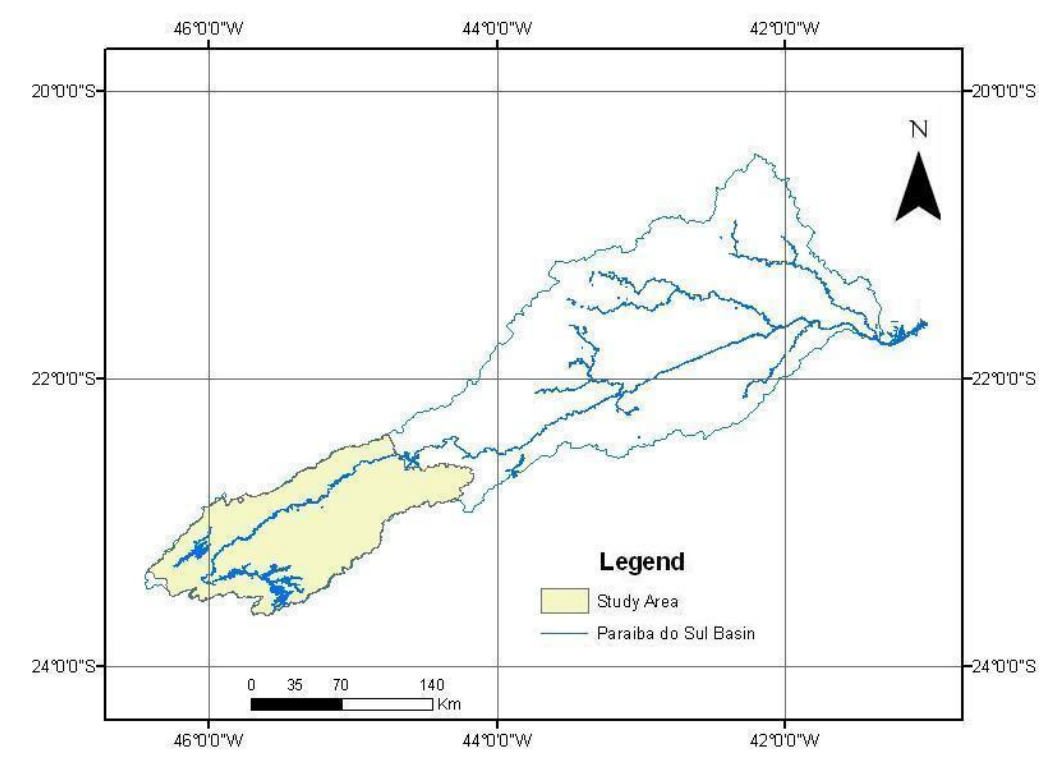

Figure 1. Study area (Paraíba do Sul Basin - São Paulo State). 
Paraíba do Sul Basin is very important in the history, culture and economy of Brazil with a large amount of urbanization and industrial activity along the Paraíba do Sul River. The basin is characterized by heterogeneous geomorphology, hydrology and soils with elevations varying from about $400 \mathrm{~m}$ in alluvial plains up to more than $2400 \mathrm{~m}$ in the Mantiqueira mountain ridge. Historically, human activity dramatically transformed the regional landscape, reducing forested areas from nearly $81 \%$ to $8.0 \%$ over the last 300 years (Fujieda et al., 1997). Currently, the landscape is a complex mosaic of grazing, forest, and urban areas. The population of the Paraíba do Sul Basin was approximately 6,400,000 in 2010 and expanded greatly in the last 30 years (CEIVAP, 2011). Cities continue to expand near or on alluvial plains, contributing to the reduction and elimination of wetland ecosystems and occupying a significant part of the floodplain.

Because of its strategic geographical position, multi-purpose reservoirs (electricity generation, flood control and flow regulation) were built first in the $1950 \mathrm{~s}$, and later in the 1970s. Since 1952, water has been diverted from the Paraíba do Sul River into the Guandu River water treatment plant in the Rio de Janeiro State. About 8.7 million people living outside of the basin (in Rio de Janeiro Metropolitan Region) depend on it for water supply. In the study area, mean river discharge is $217 \mathrm{~m}^{3} / \mathrm{s}$. The largest withdrawals of water are made for agricultural irrigation $\left(10.4 \mathrm{~m}^{3} / \mathrm{s}\right)$, followed by industrial use, $6.5 \mathrm{~m}^{3} / \mathrm{s}$ and domestic use, $3.4 \mathrm{~m}^{3} / \mathrm{s}$ (Sao Paulo, 2012). Therefore, the Paraíba do Sul River is an example of complex multipurpose water resource management that links hydropower production to agricultural, industrial and domestic water use.

Previous studies have documented the bimodal character of the annual cycle of precipitation in southeast Brazil (Braga and Molion, 1999), with dry and wet seasons consistent with the transition from tropical to mid-latitude climate regimes. In the Paraíba do Sul Basin, the average annual precipitation is in the order of $1,400 \mathrm{~mm}$, but exhibits large inter-annual variability ranging between $800 \mathrm{~mm}$ and $2000 \mathrm{~mm}$. Severe droughts occurred in 1943/1944, 1953-1957, 1963, 1968, 1984, 1994, 1997 and 2001; whereas 1947, 1976, 1983 and 2000, 2008-2010 were exceptionally wet years. Dry and wet spells (1 - 2 years) alternate frequently in the observations.

In 2001, a severe drought was blamed for the severe reduction in water levels in the reservoirs of many Brazilian hydroelectric power plants (Simoes and Barros, 2007). By September 2001, the reservoirs were working at minimum capacity (about 20\% of the total volume), evidence of the failure of existing energy and water resource management plans to meet unexpected shortages. The shortage continued until 2004. In contrast, in 2009 a very rainy period began. In January 2010, São Luis do Paraitinga, a small town located about 200 $\mathrm{km}$ from São Paulo, was devastated by a flood, and many historical buildings collapsed. In the last three years, other towns of different sizes have been affected along the Paraíba do Sul River.

The region therefore presents a high uncertainty in the long-term assessment of water resources with very high intra- and inter-annual variability in precipitation.

\subsection{Database}

Several topographic maps are available in the study area ArcGIS $^{\circledR}$ and AutoCAD ${ }^{\circledR}$ formats) including surveys undertaken at 1:250,000 and 1:50,000 scales covering the entire basin. For the basin size $\left(13,500 \mathrm{~km}^{2}\right)$, this level of topographic scale is suitable and represents a better model that those found in other Brazilian regions. Digitalized topographic maps at a larger scale $(1: 10,000)$ are available for only a very small fraction in the basin. The Digital Elevation Model (DEM) was derived from a topographic map at 1:250,000 scale, 30-by-30 minute quadrangle IBGE maps. 


\subsection{Methodological procedures}

Integrating GIS and hydrological models presents a great challenge because is difficult to combine, in the same environment, a non-GIS hydrological model that is coupled to the GIS data input or output data. According Shamsi (2002), the Integration Method represents the closest relationship between the GIS and the floodplain models. In this case, two integration approaches are possible: 1) GIS Model Integration - all the four tasks of creating model input, editing data, running the model, and displaying output results are available in GIS. 2) Model Based Integration - GIS modules are developed in or are called from a computer model

The relationship between ArcGIS ${ }^{\circledR}$ and ArcHydro is an example of GIS model integration because all tasks are developed in the GIS environment. ArcHydro is a hydrologic information system that is a synthesis of geospatial and temporal data supporting hydrologic analysis.

ArcHydro framework is the simplest way of using this software, providing a compact data structure for storing the most important geospatial data. The framework contains geospatial information organized in several levels: geodatabase, feature data set, geometric network, feature class and relationship elements (Figure 2). Geodatabase is a Microsoft Access (.mdb) file used as a relational database file; Feature database set is a folder that stores feature classes within a geodatabase with a defined map projection and coordinate system; Geometric Network is used in topologic operations; Feature Class is where the individual geographic features are stored; Relationship is where features from one class are related to those in another. In the other words, each watershed, water body, and monitoring point is related to a hydro junction on the network.

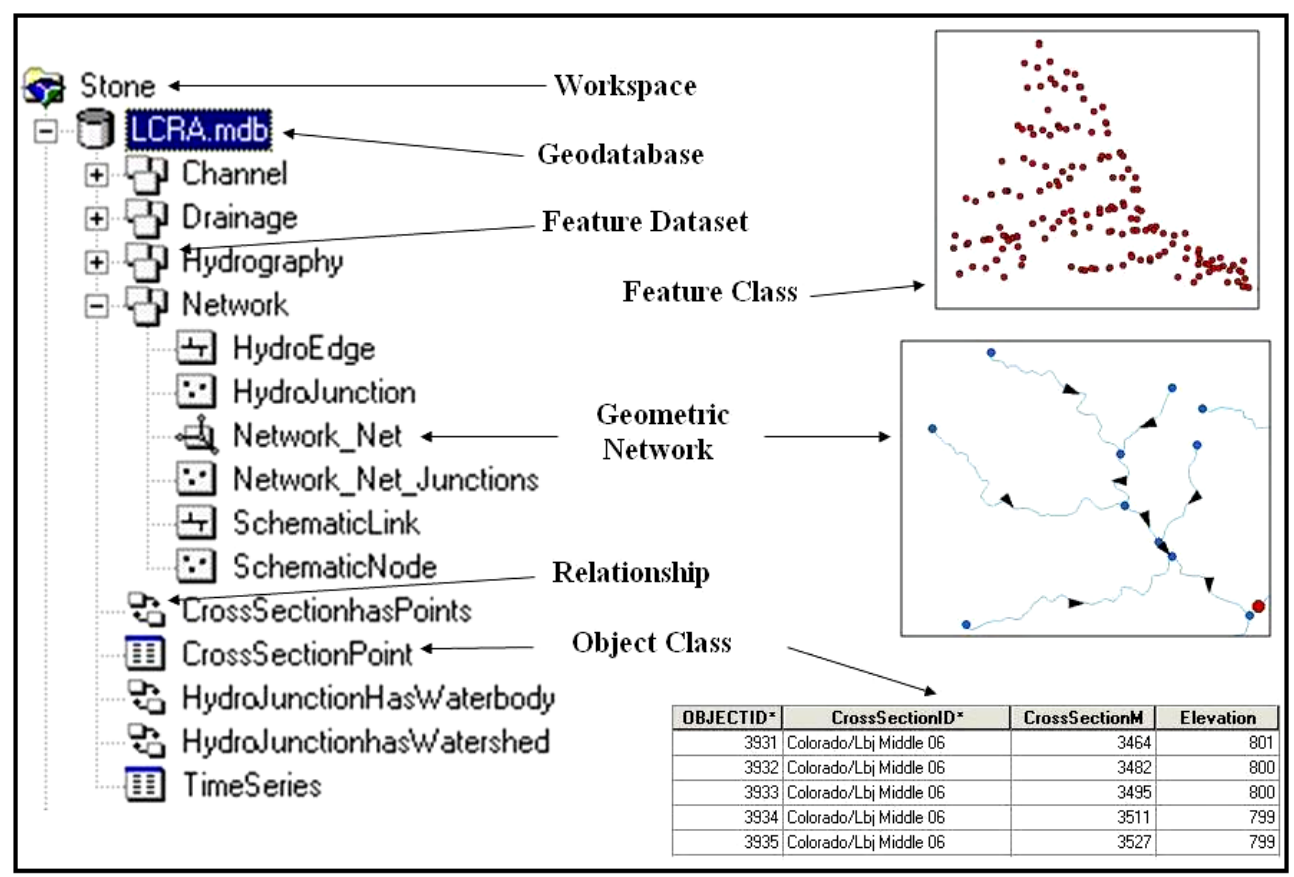

Figure 2. The components of the ArcHydro Model.

Source: modified from Maidment (2002).

Therefore, for an ArcHydro project the first step is collect GIS data commonly represented as feature classes, which are collections of geometric objects (points, lines, or polygons) that share common themes and attribute types. A typical resource for hydrological data is the National Hydrography Dataset (NHD) for the United States and HydroWeb/ANA for Brazil. The NHD includes everything necessary for a simple Arc Hydro model. However, 
in many regions worldwide, considerable preparation is needed before the database can be loaded into the ArcHydro database.

After preparing the data, a personal geodatabase is created, in which all of the Arc Hydro objects (feature classes, tables) will be stored. During this process, it is important to select a correct projection system and spatial reference frame, which should be one that will accurately represent different geographic areas of the watershed of interest. Geodatabe works best when the feature classes have the correct class names. For that, a Arc Hydro schema is applied, which mainly consists of objects such as feature datasets, feature classes and tables, and relationships among them (for more details, see Maidment, 2000). Figure 3 shows a typical geodatabase with objects that relate to one another. Hydropoint represents point features such as gauge station, Hydroedge represents line shapefile such as drainage, and Watershed represents a polygon feature class, which contains any subdivision of the landscape into drainage areas.

One of the important characteristics of the ArcHydro system is to construct water flow network. The final Arc Hydro Network creates a well-defined topology among polygon features (watershed boundary), lines (drainage system) and points (monitoring points). Therefore, HydroEdge and HydroJunction form a geometric network called HydroNetwork (Figure 3). This way, ArcGIS ${ }^{\circledR}$ can now be used to trace paths between any two network locations. Figure 3 shows the topological connectivity of partial drainage network of the study area near the river outlet.

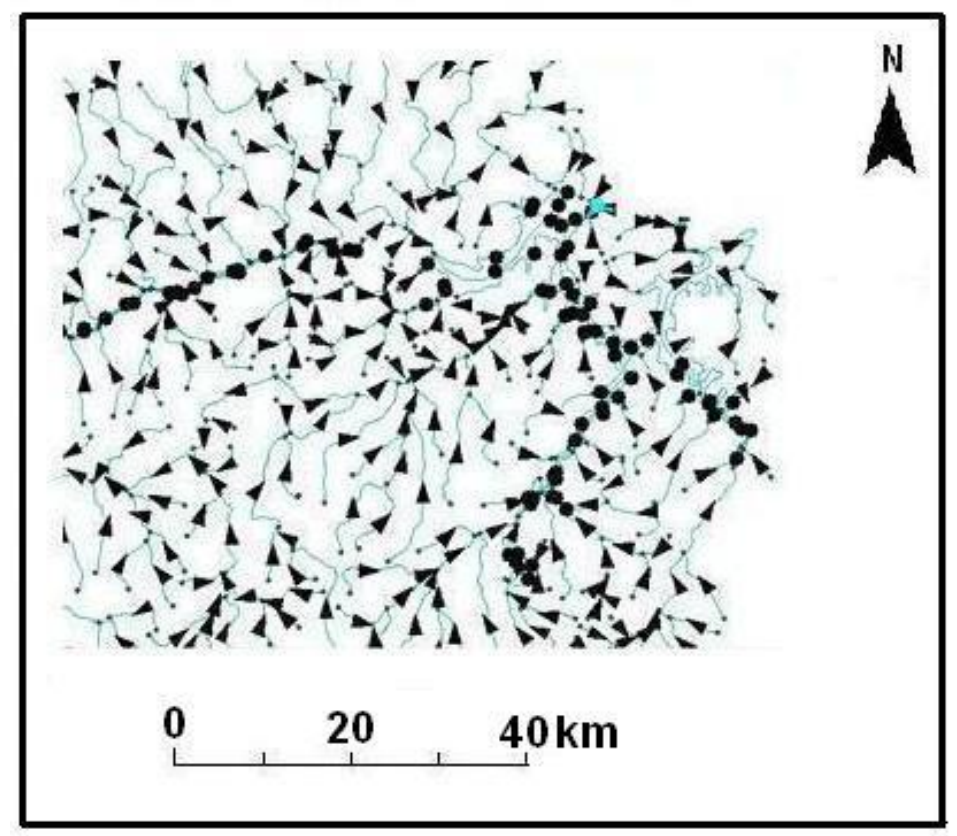

Figure 3. Drainage network connectivity determined by the flow direction grid in the downstream of the Paraíba do Sul Basin.

\section{RESULTS AND DISCUSSION}

The first step in hydrological modeling is to establish a model area by defining the outline of the watershed boundary. Since the model is distributed, which is supposed to describe flow processes in each and every point inside a catchment, a consistent digital elevation model (DEM) is needed to delineate the drainage and to estimate the parameters related to the topography. 
In this research, the gridded data is derived from a TIN surface (Figure 4a) using spatial analysis tools available in GIS software. A DEM more appropriately represents land surface and drainage flow, as compared to TIN, because of its regular cell structure. A Hydrology DEM is generated which is a DEM with no sink areas. The sink areas are pixels which have heights that are lower than neighboring pixel values. For drainage analysis to proceed, all sinks need to be filled using available process within the Arc Hydro.
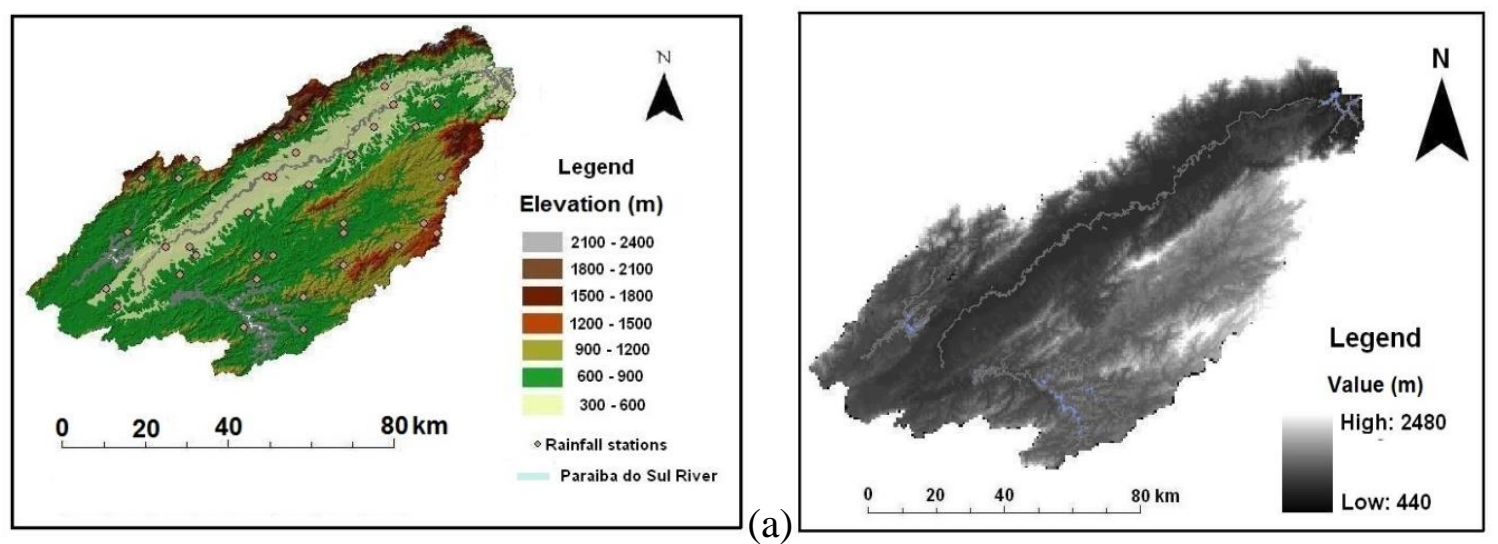

Figure 4. (a) TIN model; (b) Digital Elevation Model (DEM).

This first grid derived from the elevation model grid (DEM) is the flow direction grid (Figure 5a). A flow direction grid consists of values that indicate from which neighboring cell the water will flow. All raster operations involved in the watershed delineation are derived from the premise that water flows downhill according the eight-direction pour point model (Oliveira et al., 2000). It is important to note that the DEM must have enough precision of elevation measurement to support correct flow direction determination. Large extents of flat areas might produce a natural drainage pattern. The Paraíba do Sul Basin could be an example of such a situation, where the floodplain associated with the Paraíba do Sul River occupies an expansive area in the middle of the basin as can be seen in Figure 4a.

Flow accumulation is calculated from the flow direction grid. As highlighted by Oliveira et al. (2000), from the physical point of view the flow accumulation grid is the drainage area measured in units of grid cells. Therefore, it indicates how many cells are upstream or upslope of the current cell. According this model, water in a given cell can flow to one or more of its eight adjacent cells. The resulting flow direction is encoded 1 for East, 2 for Southeast, 4 for South, 8 for Southeast, 16 for West, 32 for Northwest, 64 for North and 128 for Northeast. Flow accumulation has been used along with flow direction, flow length and slope for different applications, such as flood forecasting (Kraus, 2000; Chen et al., 2003). The flow accumulation grid for the Paraíba do Sul Basin clearly shows how drainage areas are accumulated in the downstream sector of the study area (Figure 5a). With a flow accumulation grid, streams may be defined through the use of a threshold drainage area or the flow accumulation value (Oliveira et al., 2000). The cell values are assigned as 1, where there is a stream and "nodata" elsewhere. Therefore, all the stream cells are labeled identically with a value of 1, which were renamed as river channels (Figure 5b).

To define catchments for each stream link, the flow direction grid is used to define the zone of cells whose drainage flows through each stream link (Oliveira et al., 2000). The results of the delineation are stored in a catchment grid. Figure 5c shows catchments and hydrographic reaches for the study area. Note each hydrographic reach has only one catchment. This raster grid may be converted into a set of catchment polygons using ArcHydro (or ArcGIS ${ }^{\circledR}$ ) raster-vector conversion functions. 


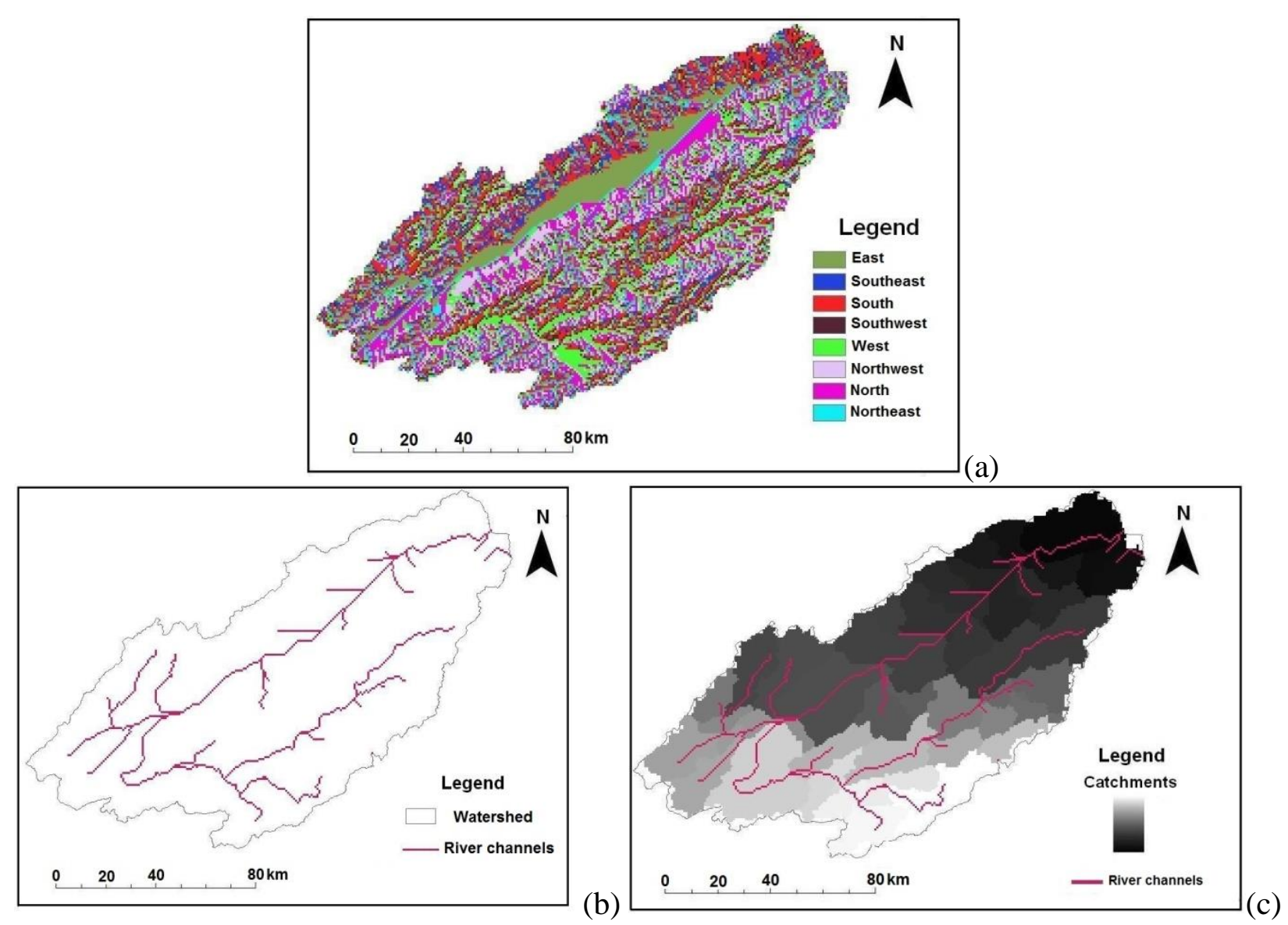

Figure 5. (a) The flow direction grid of the Paraíba do Sul Basin; (b) Drainage lines; (c) Catchment delineation.

\section{CONCLUSION}

The methodology presented in this paper offers new features that enhance the ability to create more accurate topologically based models of a hydrologic network and its relevant associated attributes. ArcHydro provides a set of objects and features that can be used as a starting point for many water resource projects. On the other hand, the derived data sets obtained from ArcHydro can assist hydrographic basin committees to make better informed decisions regarding the hydrology variables.

The next steps in this research are: a) to include the location of the multipurpose reservoirs situated along the Paraíba do Sul River; b) to incorporate rainfall time series data in ArcHydro to build a hydrologic data model within a GIS environment in order to produce a comprehensive spatial-temporal model.

\section{ACKNOWLEDGEMENTS}

The author acknowledges the State of Sao Paulo Research Foundation (Fundação de Amparo à Pesquisa do Estado de São Paulo - FAPESP) for the financial support of this research (2009/10573-2). 


\section{REFERENCES}

BRAGA, B. P. F.; MOLION, L. C. B. Assessment of the impacts of climate variability and change on the hydrology of South America. In: VAN DAM, J. C. (Ed.). Impacts of climate change and climate variability on hydrological regimes. Cambridge: Cambridge University Press, 1999. p. 21-35.

COMITÊ DE INTEGRAÇÃO DA BACIA HIDROGRÁFICA DO RIO PARAÍBA DO SUL - CEIVAP. Bacia do Rio Paraíba do Sul - Subsídios às ações de melhoria da gestão 2011. Resende: AGEVAP/CEIVAP, 2011. Technical Report.

CHEN, Y.; HU, J.; YU, J. A flash flood forecast model for the Three Gorges basin using GIS and remote sensing. IAHS publication, n. 282, p. 282-287, 2003.

CLARK, M. Putting water in its place: a perspective on GIS in hydrology and water management. In: GURNELL, A. M.; MONTGOMERY, D. R. (Eds.) Hydrological application of GIS. Chichester: John Wiley, 1999. p. 3-14.

COLSON, T. P.; GREGORY, J. D.; MITASOVA, H.; NELSON, S. Comparison of stream extraction models using LIDAR DEMs. In: AWRA SPRING CONFERENCE, 4., 8-10 May 2006, Houston. Proceedings... [S.1.]: AWRA, 2006.

DOST, R. J. J. Hydrologic information systems as a support tool for water quality monitoring: a case study in Bolivian Andes. 2005. Thesis (M. S.) - International Institute for Geo-information Science and earth Observation, Enschede, 2005.

FARIA, D. A. Influência do uso e ocupação do solo na qualidade da água da bacia hidrográfica do ribeirão Guaratinguetá (SP). 2012. Thesis (Master) - Graduate Program in Civil and Environmental Engineering, Universidade Estadual Paulista, 2012.

FUJIEDA, M.; KUDOH, T.; DE CICCO, V.; CARVALHO, J. L. Hydrological processes at the subtropical forest catchments of the Serra do Mar, Sao Paulo, Brazil. Journal of Hydrology, v. 196, p. 26-46, 1997. http://dx.doi.org/10.1016/S0022-1694(97)00015-2

KARAGIOZI, E.; ANDERADAKIS, E.; FOUNTOULIS, I; KONSTANTINIDIS, A.; NTOUROS, K. Flood hazard assessment based on geomorphological analysis with GIS tools - The case of Laconia (Peloponnesus, Greece). In: SYMPOSIUM GIS, 20114, Ostrava. Proceedings... Ostrava: [s.n.], 2011.

KAWASAKI, A.; TAKAMATSU, M.; HE, J.; ROGERS, P. Potential impact of precipitation and land-cover changes on stream flow in Srepok River Basin in Vietnam and Cambodja: an analysis process for local level water resources adaptation. ABCD-GIS Working Groups. Harvard University, 2008a.

KAWASAKI, A.; HERATH, S.; MEGURO, K. Developing a universal water resource assessment model for sustainable water security: the case of Kanagawa Basin, Japan and the Mekong River Basin. ABCD-GIS Working Groups. Harvard University, $2008 b$.

KRAEMER, C.; PANDA, S. S. Automating archydro for watershed delineation. GEORGIA WATER RESOURCES CONFERENCE, April 2009, Athens. Proceedings... Athens: University of Georgia, 2009. 
KRAUS, R. A. Floodplain determination using ArcView GIS and HEC-RAS. In: MAIDMENT, D.; DJOKIC, D. (Eds.) Hydrologic and hydraulic: modeling support. Redland: ESRI Press, 2000. p. 177-189.

MAATHUIS, B. H. P.; WANG, L. Digital elevation model based hydro - processing. Geocarto International, v. 21, p. 21-26, 2006.

MAIDMENT, D. R. ArcHydro. GIS for water resources. Redland: ESRI Press, 2002.

OLIVEIRA, F.; FURNANS, J.; MAIDMENT, D.; DJOKIC, D.; YE, Z. Drainage systems. In: MAIDMENT, D. R. (Ed.) ArcHydro. GIS for water resources. Redlands: ESRI Press, 2000. p. 55-86.

RAMROOP, S. Flooding analysis strategy using GIS. ESRI INTERNATIONAL USER CONFERENCE, August 2005, San Diego. Proceedings... [S.1.]: ESRI, 2005.

SAO PAUlO (STATE). Water resources situation in the Sao Paulo State. São Paulo: Water and Electrical Energy Department (DAEE), 2012.

SHAMSI, S. U. GIS application in floodplain management. ESRI INTERNATIONAL USER CONFERENCE, August 2002, San Diego. Proceedins... [S.1.]: ESRI, 2002.

SIMOES, S. J. C.; BARROS, A. P. Regional climate variability and its effects on Brazil's 2001 energy crisis. Management Environment Quality, v. 18, n. 3, p. 263-273, 2007.

SOARES, P. V.; PEREIRA, S. Y.; SIMOES, S. J. C.; BERNARDES, G. P.; BARBOSA, S.; TRANNIN, I. The definition of potential areas of infiltration in the Guaratingueta watershed, Southeast Brazil. An integrated approach using physical and land use elements. Environmental and Earth Sciences, v. 67, p. 1685-1694, 2012. http://dx.doi.org/10.1007/s12665-012-1610-6

VALERIANO, M. M. Modelo digital de variáveis morfométricas com dados SRTM para o território nacional: o projeto TOPODATA. SIMPÓSIO BRASILEIRO DE SENSORIAMENTO REMOTO, 12., May 2005, Goiânia. Anais... São José dos Campos: INPE, 2005. p. 1-8. 